\title{
POTENTIALS AND COSTS OF VARIOUS RENEWABLE GASES: A CASE STUDY FOR THE AUSTRIAN ENERGY SYSTEM BY 2050
}

\author{
Daniel C. Rosenfeld *, Johannes Lindorfer, Hans Böhm, Andreas Zauner and Karin \\ Fazeni-Fraisl
}

Energieinstitut an der Johannes Kepler Universität Linz, Altenberger Straße 69, 4040 Linz, Austria

Article Info:
Received:
24 March 2021
Revised:
3 August 2021
Accepted:
23 August 2021
Available online:
30 September 2021
Keywords:
Anaerobic digestion
Power-to-gas
Gas greening
Biomass gasification
Technoeconomic analysis

\section{INTRODUCTION}

The major challenge of this century is climate change. To tackle this challenge, it is necessary to find measures to limit the temperature rise to a maximum of $2^{\circ} \mathrm{C}$, or even $1.5^{\circ} \mathrm{C}$ in an optimal case (Gao et al., 2017). Therefore, it is necessary to significantly reduce global $\mathrm{CO}_{2}$ emissions and reach, at a minimum, carbon neutrality within the next 20 to 30 years.

On a European scale, in 2011, the European Union published a "roadmap for moving to a competitive low-carbon economy in 2050." This roadmap aims for a greenhouse gas emission reduction of $80 \%$ to $95 \%$ by 2050 (European Commission, 2011). In 2019, the European Union published "new green deal" priority energy efficiency measures. However, these measures further include the substitution of $72 \%$ of current fossil-based energy by renewable energy since this amount cannot be reduced by efficiency measures (European Commission, 2019). This goal could be reached by either electrification using renewable electricity or substitution with a renewable alternative such as fossil natural gas with synthetic natural gas (SNG). This action plans to reach net carbon neutrality by 2050 are mainly being carried out on a national basis.

The objective of the current program of the Austrian Federal Government is to provide $100 \%$ of Austria's electricity supply from renewable energy sources by 2030 . Doing so requires an increase in renewable electricity generation of 27 TWh in total (11 TWh photovoltaic, 10 TWh wind power, 5 TWh hydropower, and 1 TWh biomass). Regarding gas supply, an expansion and support program is planned to promote the production of renewable gas (i.e., biomethane, green hydrogen, and SNG based on renewable electricity) by 2030 . The aim is to feed 5 TWh of "green gas" into the natural gas grid by 2030. A full decarbonization of the Austrian economy, aiming for carbon neutrality, should be reached by 2040 (Republik Österreich, 2020). Therefore, the Austrian natural gas demand - 87.2 TWh in 2018 (British Petroleum p.l.c, 2019) - must be reduced and fully substituted by renewables. 
However, as of today only $3,000 \mathrm{Nm}^{3} / \mathrm{h}$ biomethane from 15 biomethane plants is fed into the gas grid (Kompost \& Biogas Verband Österreich, 2021). With annual full load hours of $8,000 \mathrm{~h}$ per year and a lower heating value (LHV) of $9.944 \mathrm{kWh} / \mathrm{Nm}^{3}$, this would correspond to about $239 \mathrm{GWh} / \mathrm{a}$. Therefore, only about $0.2 \%$ of today's natural gas demand can be provided from biomethane. This example shows that fossil energy carriers must be reduced drastically, while renewable ones must be used in larger quantities. This means that the electrification rate of the industrial, household, and mobility sectors should be increased while simultaneously reducing dependency on fossil energy carriers (Schiffer \& Manthiram, 2017). Furthermore, renewable methane could serve as a bridge to the full electrification of private households. Nevertheless, some industries rely on carbon-containing energy carriers such as natural gas as part of their processes; an example is the chemical industry (Lechtenböhmer et al., 2016). Therefore, it is necessary to produce renewable methane to fulfill the need for carbon in industrial routes or for high energy density demands, such as in aviation.

This results in many studies focusing on the potential of bioenergy and renewable methane. Mostly on a national scale. (Steubing et al., 2010) conducted, that about $7 \%$ of the Switzerland energy demand could be covered by bioenergy. Another study, focusing on Swiss manure potentials stated that about 250 GJ gross biogas per year (corresponding to about $69 \mathrm{MWh}$ per year) could be produced resulting in a $\mathrm{GHG}$ reduction of $159 \mathrm{kt}$ of $\mathrm{CO}_{2}$,eq. (Burg et al., 2018). A study for turkey has shown that about 2.14 billion $\mathrm{Nm}^{3}$ per year (corresponding to about 21 TWh per year) of biomethane could be produced from cattle and sheep manure till 2026 (Melikoglu \& Menekse, 2020). Many similar studies for different other countries were conducted in the past years. (Wang et al., 2018) analyzed the biomethane potential from slaughterhouse wastes in the US. (O'Shea, Wall, McDonagh, et al., 2017) is one of only a few studies that has not focused on one source in detail, but combined industries, waste water treatment and power-to-gas for renewable methane production in Ireland. Another study of the same year (O'Shea, Wall, Kilgallon, et al., 2017) focused on the theoretical potential of biomethane from different biogenic sources and combined the potential study with an economic analysis. Another study for Ireland has focused on the bio-SNG potential from waste and residues. It was conducted that about 10.18 PJ Bio-SNG per year (corresponding to about 2.8 TWh per year) could pe produced in Ireland (Singlitico et al., 2018).

For Austria there are several recent studies focusing on the renewable methane potentials. (Daniel C Rosenfeld et al., 2020) stated a theoretical production potential of 900 million $\mathrm{Nm}^{3}$ per year (corresponding to about 8.9 TWh) of biomethane from anaerobic digestion of organic waste materials and also includes the potential recovery of $P$ and N. (Dißauer et al., 2019) focused on renewable methane production of woody biomass and organic wastes via biomass gasification. For the year 2050 the study has shown a theoretical potential of renewable methane of 10billion $\mathrm{Nm}^{3}$ per year (corresponding to $99 \mathrm{TWh}$ per year). The realizable potential was calculated with 4 billion $\mathrm{Nm}^{3}$ per year (corresponding to 40 TWh per year). Furthermore, the study included a cost perspective for renewable methane from gasification showing specific production costs of 4.3 to $5.5 €$-cent per kWh.

As shown by this overview most studies either focus only on the potential or the cost analysis. If in only a few cases the cost perspective is combined with a potential analysis, the study focuses only on one technology. Furthermore, studies like (Dißauer et al., 2019) and (O'Shea, Wall, Kilgallon, et al., 2017) have shown that currently the most relevant hurdles for renewable energy systems are their corresponding costs, which is one reason for the slow transition from fossil to sustainable energy. Therefore, studies that investigate future potentials must include cost structures and the economic impact of renewable energy systems. Furthermore, for a better understanding of the energy sector transition studies that evaluate the combination of different technologies to fully use the potential for renewable methane production are beneficial.

Within this work the technically available potentials for green gases from anaerobic conversion and biomass gasification of organic waste materials, and power-to-gas $\left(\mathrm{H}_{2}\right.$ and SNG based on renewable electricity) for Austria, as well as their approximate energy production costs, and quantifies their economic effects on the Austrian energy system were analyzed. Aim of the work is therefore to provide a broad overview of potential renewable gas production routes. Furthermore, to have a sustainable system, the substrates for gasification and anaerobic digestion are limited to waste streams. This allows for a sustainable and future fit overview of renewable methane potentials till 2050.

To do so this work includes three types of analyses. First, a potential analysis was carried out for the methane production potential from anaerobic digestion and biomass gasification from organic waste materials, as well as power-to-gas. Subsequently, a technoeconomic analysis was conducted to gather information about the costs of the different potential types. Finally, an expansion scenario for the plants was created to fully exploit all potentials by 2050 .

\section{METHODOLOGY}

\subsection{Description of the Analyzed System}

This work focuses on the renewable methane generation potential of biogenic (waste) streams in Austria. For this analysis, data concerning the anaerobic digestion potential of residual and waste materials and biomass for dual fluidized gasification were extracted from existing literature (Bundesanstalt für Agrarwirtschaft, 2016; Bundesministerium Nachhaltigkeit und Tourismus, 2019; FNR, 2013; Reisinger, 2012; Universität Rostock, 2007).

Three technology pathways were investigated for the purpose of developing a full renewable methane generation potential. Waste streams with high moisture content that are well suited for anaerobic digestion should be used for biomethane generation. The biogenic $\mathrm{CO}_{2}$ that is separated from the biogas as part of the gas cleaning (including also cleaning steps like moisture and $\mathrm{H}_{2} \mathrm{~S}$ separation) to reach biomethane in grid quality $\left(\mathrm{CH}_{4} \geq 96 \%\right.$ (ÖVGW, 2011)) should be further processed with a power-to-gas approach. 
In general, the separation step could be avoided by adding the cleaned biogas (that only includes $\mathrm{CH}_{4}$ and $\mathrm{CO}_{2}$ ) directly to the power-to-gas plant. However, e.g. higher volume flows or the operational systems linkage are potential associated problems to solve. While it is expected, that efficient biomethane plants are operated with more than 8,000 hours per year, power-to-gas plants utilizing fluctuating renewable electricity production typically would operate with only about 3,500 hours per year. Therefore, a storage of either the biogas or only the $\mathrm{CO}_{2}$ is necessary for optimal operation. Since it is desirable to have the highest possible baseload capacity for renewable methane, this work considers a $\mathrm{CO}_{2}$ storage instead of a biogas storage. This allows production of the maximum amount of renewable methane from organic waste. Furthermore, lignocellulosic biomass streams should be used for conversion to SNG, with a dual fluidized bed gasifier coupled with a methanation unit for syngas upgrading. Figure 1 shows the analyzed technology pathways as well as their potential fields of application.

\subsection{Potential Analysis}

According to (Batidzirai et al., 2012), the theoretical, technical, economic, and sustainable potential (see Fig- ure 2) can be differentiated. The highest potential comes from the theoretical potential since it includes all available quantities without considering technical or economic feasibilities of exploitation (Thrän et al., 2013). The technical potential is reduced by technical constraints such as salvage rates and technical restrictions (Brosowski et al., 2015). The economic potential is further decreased since it only includes the economically feasible potential (Umweltveränderungen, 2009). In this work, the technical potential of biomethane production from the organic waste fraction and its synergy with power-to-gas technology is evaluated, as well as the SNG production potential from biomass gasification, as described in the previous section.

An overview of the reduction factors for calculating the technical potential is shown in Table 1.

The technical potential $\left(P_{\text {technical }}\right)$ is calculated by applying the ratio of technical to theoretical potential $(p)$ to the theoretical potential $\left(P_{\text {theoretica }}\right)$ as described in Equation 1. The index $\mathrm{n}$ represents the substrate category that is calculated.

$P_{\text {technical, } n}=P_{\text {theoretical, } n} * p_{n}$

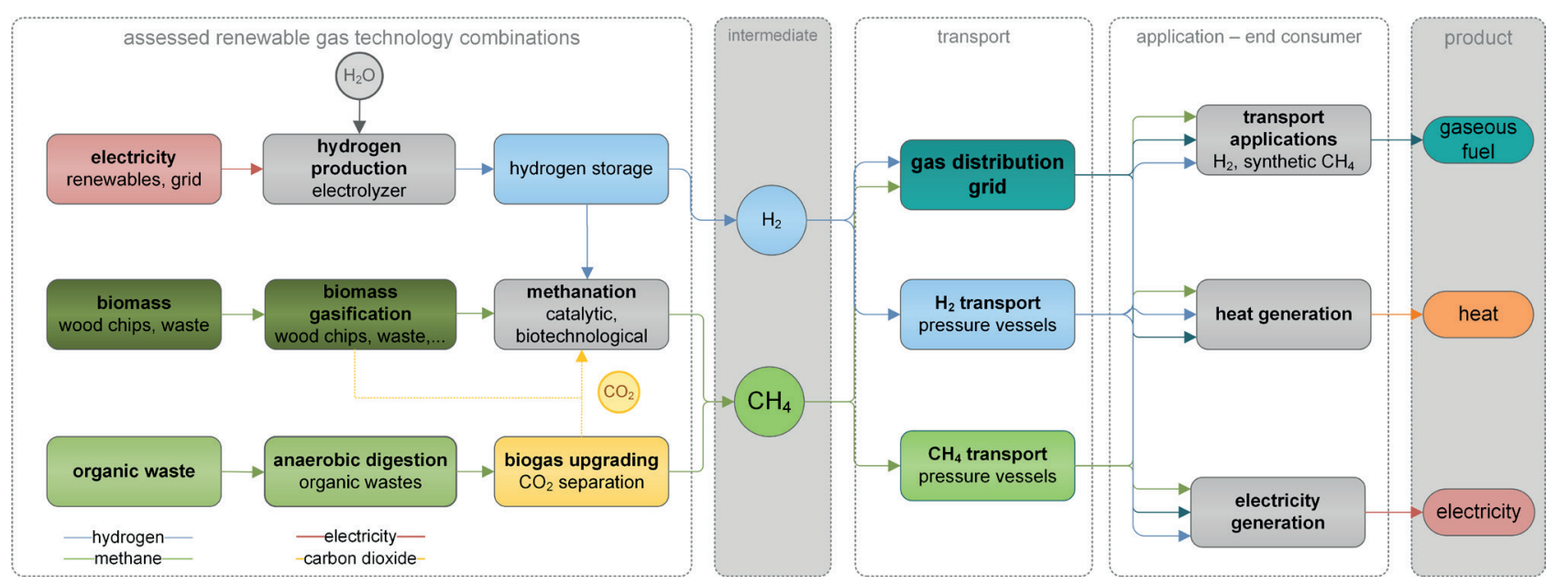

FIGURE 1: Renewable gas pathways (Daniel C. Rosenfeld, 2020).

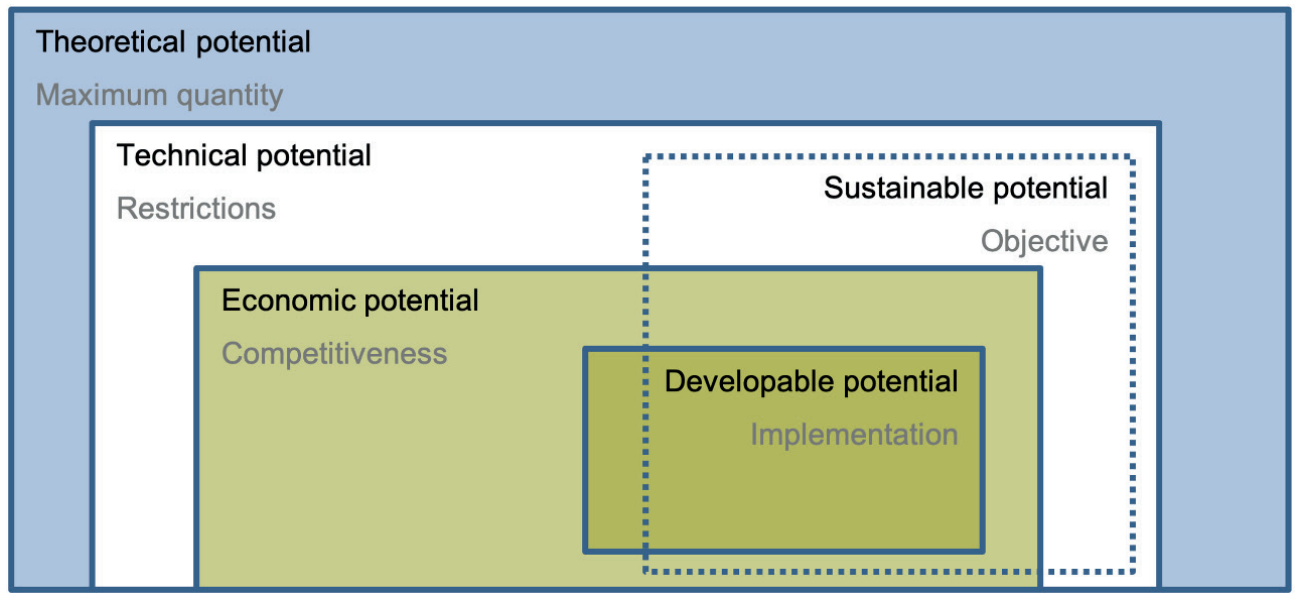

FIGURE 2: Schematic overview of types of potentials (Steubing et al., 2010). 
TABLE 1: Technical potential characteristics for biomethane from organic waste.

\begin{tabular}{|c|c|c|}
\hline Substrate & $\begin{array}{l}\text { Ratio of technical to } \\
\text { theoretical potential }\end{array}$ & Source \\
\hline Farm manure ${ }^{a}$ & $70 \%$ & (Erler et al., 2013) \\
\hline Straw & $30 \%$ & (Erler et al., 2013) \\
\hline Beet leaves ${ }^{c}$ & $20 \%$ & (Erler et al., 2013) \\
\hline $\begin{array}{l}\text { Biowaste from } \\
\text { households }^{d}\end{array}$ & $90 \%$ & (Erler et al., 2013) \\
\hline $\begin{array}{l}\text { Bush, grass and tree } \\
\text { cuttings }\end{array}$ & $90 \%$ & (Erler et al., 2013) \\
\hline Sewage sludge ${ }^{f}$ & $50 \%$ & Own assumption \\
\hline Food fats and oils ${ }^{g}$ & $60 \%$ & Own assumption \\
\hline Garden composting ${ }^{\mathrm{h}}$ & $0 \%$ & Own assumption \\
\hline
\end{tabular}

a The share of technical potential considers storage and withdrawal losses as well as livestock housing rates. In addition, only farms with more than 50 life stock unit (LSU) were considered.

${ }^{b}$ The share of technical potential takes into account the long-term preservation of soil fertility, salvage quotas, and existing straw uses in livestock farming and horticulture.

c Technical potential is equal to salvage quota.

d Technical potential takes into account storage and transport losses; this fraction is additionally subtracted from the theoretical potential.

${ }^{\text {e }}$ For the quantities of green waste already collected today, $90 \%$ is also assumed for the technical potential, based on the biowaste material. ${ }^{f}$ It one assumes that about $50 \%$ of the sewage sludge from wastewater treatment plants with a capacity greater than a population equivalent of 60 is available as the technical potential.

${ }^{g}$ The survey includes the quantities that are already collected today.

${ }^{h}$ It is assumed that the connection rate to the organic waste collection in the municipalities will increase by 2040. In the long term, home garden composting will therefore be merged with biogenic waste, and, by 2040, this biogenic waste will also gradually become usable for anaerobic digestion. However, the potential is still theoretical.

\subsubsection{Biomethane Potential}

To estimate the technical biomethane yield potential, as a first step, all usable residue flows in Austria were identified. Subsequently, the theoretical biomethane yield potential for Austria was calculated on the basis of biomethane yield factors for the different waste fractions. The exact values that were used in the calculation can be found in the supplementary materials.

The selected waste streams that were considered were manure, straw, waste from food production, biowaste from households, green cuttings, food and kitchen waste, and sewage sludge. Waste food in residual waste and garden composting was considered as well but assumed to be zero for the technical potential since these categories cannot be gathered technically. In terms of agricultural facilities, it was assumed that cow, poultry, pig, and horse manure without straw could be gathered only during winter months since in summer months animals are likely held outside and gathering is not feasible. Furthermore, only agricultural facilities with more than 50 livestock animals were considered in this study since it is difficult to collect manure at sites with fewer livestock animal. In terms of straw, only cereal, maize, and rape straw, as well as beet leaves, were considered since other types of straw do not exist in sufficient amounts in Austria.

These waste streams are then fed to a biomethane plant based on anaerobic digestion. Depending on the waste stream, different biomethane yields can be attained via this biochemical process. As depicted in Table 2, sewage sludge has the highest biomethane production value,

TABLE 2: Methane and biogas production rates.

\begin{tabular}{|c|c|c|c|c|}
\hline Substrate & Methane production rate & Biogas production rate & Methane share & Source \\
\hline \multicolumn{5}{|l|}{ Manure } \\
\hline Cow dung & & $60 \mathrm{Nm}^{3} / \mathrm{t}_{\mathrm{DM}}$ & 60 vol.- $\%$ & (LFL, 2019) \\
\hline Pig dung & & $60 \mathrm{Nm}^{3} / \mathrm{t}_{\mathrm{DM}}$ & 60 vol.. $\%$ & (LFL, 2019) \\
\hline Pig manure & & $20 \mathrm{Nm}^{3} / \mathrm{t}_{\mathrm{DM}}$ & 60 vol.- $\%$ & (LFL, 2019) \\
\hline Poultry manure & & $80 \mathrm{Nm}^{3} / \mathrm{t}_{\mathrm{DM}}$ & 60 vol.. $\%$ & $(L F L, 2019)$ \\
\hline Horse manure w/o straw & & $60 \mathrm{Nm}^{3} / \mathrm{t}_{\mathrm{DM}}$ & 60 vol.- $\%$ & (LFL, 2019) \\
\hline \multicolumn{5}{|l|}{ Straw } \\
\hline Cereal straw & & $331 \mathrm{Nm}^{3} / \mathrm{t}_{\mathrm{DM}}$ & 51 vol.. $\%$ & (LFL, 2019) \\
\hline Maize straw & & $331 \mathrm{Nm}^{3} / \mathrm{t}_{\mathrm{DM}}$ & 51 vol.-\% & $(\mathrm{LFL}, 2019)$ \\
\hline Rape straw & & $187 \mathrm{Nm}^{3} / \mathrm{t}_{\mathrm{DM}}$ & 52 vol.- $\%$ & (LFL, 2019) \\
\hline Beet leaves & $105 \mathrm{Nm}^{3} / \mathrm{t}_{\mathrm{DM}}$ & & & (FNR, 2013) \\
\hline Waste from food production & $145 \mathrm{Nm}^{3} / \mathrm{t}_{\mathrm{DM}}$ & & & $\begin{array}{l}\text { (Reisinger, 2012; Universi- } \\
\text { tät Rostock, 2007) }\end{array}$ \\
\hline \multicolumn{5}{|l|}{ Other biogenic waste } \\
\hline Municipal garden and park waste & $105 \mathrm{Nm}^{3} / \mathrm{t}_{\mathrm{DM}}$ & & & (FNR, 2013) \\
\hline Cemetery waste & $105 \mathrm{Nm}^{3} / \mathrm{t}_{\mathrm{DM}}$ & & & (FNR, 2013) \\
\hline Roadside vegetation & $105 \mathrm{Nm}^{3} / \mathrm{t}_{\mathrm{DM}}$ & & & (FNR, 2013) \\
\hline Kitchen and food waste & $164 \mathrm{Nm}^{3} / \mathrm{t}_{\mathrm{DM}}$ & & & (Alibardi \& Cossu, 2015) \\
\hline Biowaste from households & $185 \mathrm{Nm}^{3} / \mathrm{t}_{\mathrm{DM}}$ & & & (KTBL, 2008) \\
\hline Bush, grass, and tree cuttings & $105 \mathrm{Nm}^{3} / \mathrm{t}_{\mathrm{DM}}$ & & & (FNR, 2013) \\
\hline Sewage sludge & $312 \mathrm{Nm}^{3} / \mathrm{t}_{\mathrm{DM}}$ & & & (Kuo \& Dow, 2017) \\
\hline
\end{tabular}


while manure has the lowest value, depending on the category.

To calculate the biomethane potential $\left(\mathrm{P}_{\mathrm{m}, \mathrm{x}}\right)$, the production rates for biomethane $\left(\mathrm{pr}_{\text {biomethane }}\right)$ are applied to the substrate potentials $\left(P_{s, x}\right)$ where $x$ stands either for the theoretical or technical potential (see Equation 2).

$P_{m, X, n}=p r_{\text {biomethane, } n} * P_{s, X, n}$

The production rates for biomethane are substrate depending and can be calculated by combining the production rate of biogas $\left(\mathrm{pr}_{\text {biogas }}\right)$ with its biomethane content $\left(x_{\text {biomethane }}\right)$ as shown in Equation 3.

$p r_{\text {biomethane, },}=p r_{\text {biogas, },} * X_{\text {biomethane, } n}$

\subsubsection{Power-to-Gas}

Another potential resource available for biochemical methane production is $\mathrm{CO}_{2}$ from biogenic sources. This potential resource can be used for a power-to-gas approach. Here, $\mathrm{H}_{2}$ is produced from renewable electricity via electrolysis to further methanate $\mathrm{H}_{2}$ with $\mathrm{CO}_{2}$ to produce SNG. Therefore, this form of sector coupling is perfectly suited to further increasing methane yields from biogenic waste. To accomplish this, $2.75 \mathrm{~kg}$ of $\mathrm{CO}_{2}$ and $0.5 \mathrm{~kg}$ of $\mathrm{H}_{2}$ are needed for the production of $1 \mathrm{~kg}$ of SNG. For a more detailed overview of power-to-gas technology, see (Götz et al., 2016; Steinmüller et al., 2014).

\subsubsection{Biomass Gasification}

In the field of thermochemical conversion of biomass (gasification), residues mainly from the categories of firewood, bark, sawmill byproducts, and woodchips were considered for utilization in the thermochemical gasification process. The theoretical potential in the categories of firewood, woodchips, and bark comprises the total amount of biomass that grows annually in Austria (Dißauer et al., 2019). The theoretical potential in the sawmill byproducts category comprises $100 \%$ of the residual biomass stream generated in sawmills (Dißauer et al., 2019). Recovery pathways for wood are very well established in Austria, as is shown in the current wood flow diagram (Strimitzer \& Höher, 2020). Therefore, estimation of a feasible potential of available wood for biomass gasification is mainly about avoiding competing uses. In determining the realizable potential, this study is guided by the assumptions from (Dißauer et al., 2019): the authors assume that $50 \%$ of the unused increment of biomass is available for gasification under the assumption that the structure of wood use in industrial sectors will remain constant in the future. The reason for the $50 \%$ reduction (apart from technical restrictions, which would result from complete utilization of the renewable volume and thus already lead to a reduction) is the idea of sustainability and possible further competing uses. Especially in terms of sustainability, not using the entire increment is important to, for example, preserve forest areas as carbon sinks (Bundesforschungszentrum für Wald, 2013). At the same time, with expected higher levels of damaged wood due to bark beetle infestation and weather extremes, demand for sawmill byproducts for pellets is expected to increase, and demand from wood heat- ing systems is expected to decrease. Thus, based on this approximate approach, a total of about 1.6 million t-atro (a ton of absolute dry wood) of forest biomass (firewood and woodchips) is realistically available for thermochemical conversion. For sawmill byproducts (including bark), about $50 \%$ of sawmill byproducts can presumably be used for gasification in the future, even if this requires a redirection of wood flows. Thus, approximately 1 million t-atro of sawmill byproducts (including bark) is available (Dißauer et al., 2019).

This technoeconomic calculation did not include wood from short rotation coppice and miscanthus like some other studies, as these would require their own cropland. Thus, they cannot be seen as residuals and are therefore not within the scope of this work (Dißauer et al., 2019), especially because studies have found that this land use change is often at the expense of food or feed production (Xie et al., 2019). Therefore, these categories were not further investigated beyond their potential.

\subsection{Technoeconomic Analysis}

To categorize the different potentials in a theoretical merit order (see Section 12), a technoeconomic analysis was performed to calculate of the levelized costs of energy (LCOE). This analysis is based on the annuity method and applied as described by (Böhm et al., 2020).

\subsubsection{Investment Costs}

As a first step, the investment-based annuity was calculated. This was done using the values for capital expenditures (CAPEX) for different years on base-scale plants as listed in Table 3.

Additionally, the assessment considers increasing process efficiencies for the different observation periods as stated in Table 3. The efficiency of the methanation process is kept constant, presuming a complete conversion. However, based on the expected role of power-to-gas in the future energy system a CAPEX decrease was given by (Böhm et al., 2020). This cost reduction also applies to water electrolysis, as the key technology for all power-to-x applications.

For biomass gasification, the CAPEX reduction potential is expected to be much lower in comparison to the power-to-gas systems. This results from its availability on industrial scale. Since there are already realized projects as for example Senden in the Netherlands (Kern et al., 2013), GoBiGas in Gothenburg, Sweden (Thunman et al., 2018) or Güssing in Austria (Hofbauer et al., 2002), it is expected that additional CAPEX decrease from scaling is not as high as with the comparatively new power-to-gas technology.

For fixed plant scales (size), the investment cost part $I_{0}$ of the LCOE is calculate from specific CAPEX according to Equation 4 (Kotowicz et al., 2018).

$I_{0}=$ CAPEX ${ }^{*}$ size

However, this calculation only describes the investment costs for the plant at reference scale (e.g. in terms of biomass gasification in this paper $25 \mathrm{MW}$ ). For differing scales the investment costs for the new scale can be cal- 
TABLE 3: Data for investment cost modelling of the main components.

\begin{tabular}{|c|c|c|c|c|c|}
\hline & & Biomass gasification & $\begin{array}{l}\text { Polymer electrolyte mem- } \\
\text { brane (PEM) electrolyzer }\end{array}$ & Methanation & $\begin{array}{c}\text { Anaerobic digester \& gas } \\
\text { upgrading }\end{array}$ \\
\hline Base scale & MW & 25 & 10 & 5 & $1-8$ \\
\hline CAPEX 2020 & $€ / \mathrm{kW}$ & $2,400^{\mathrm{a}}$ & $1,100^{c}$ & $600^{c}$ & $\varnothing 2,900^{i}$ \\
\hline CAPEX 2030 & $€ / \mathrm{kW}$ & $2,200^{\mathrm{a}}$ & $630^{c}$ & $530^{c}$ & $\varnothing 2,300^{\circ}$ \\
\hline CAPEX 2050 & $€ / k W$ & $1,900^{\mathrm{a}}$ & $270^{c}$ & $340^{c}$ & $\varnothing 2,000^{i}$ \\
\hline Efficiency 2020 & $\%_{\text {LHV }}$ & $69^{\mathrm{b}}$ & $61^{e}$ & $83^{c}$ & $40-60^{\mathrm{h}}$ \\
\hline Efficiency 2030 & $\%_{\text {LHV }}$ & $69^{b}$ & $63^{e}$ & $83^{c}$ & $40-60^{\mathrm{h}}$ \\
\hline Efficiency 2050 & $\%_{\text {LHV }}$ & $69^{b}$ & $68^{e}$ & $83^{\circ}$ & $40-60^{\mathrm{h}}$ \\
\hline Lifetime & years & $20^{a}$ & $20^{e}$ & 15 & 15 \\
\hline OPEX $_{p l}{ }^{d}$ & $\%$ & $1.5^{\mathrm{a}}$ & $3-5^{f}$ & $5^{\mathrm{h}}$ & 3 \\
\hline
\end{tabular}

a Values and assumptions were made according to the data of (Müller, 2013).

${ }^{b}$ Values for biomass gasification coupled with catalytic methanation according to the data of (Dißauer et al., 2019).

${ }^{c}$ Based on scaling effects given by (Böhm et al., 2020) for PEM electrolysis and catalytic methanation

a Operational expenditures (OPEX) for operation, maintenance, taxes, etc. in percentage of investment costs

e Based on (Smolinka et al., 2018)

${ }^{f}$ Based on (Buttler \& Spliethoff, 2018)

${ }^{g}$ Based on (Gorre et al., 2019)

${ }^{h}$ Based on (TNO, 2021) and (Boldrin et al., 2016)

'Based on (Birol, 2020; Kampman et al., 2020; Skovsgaard \& Jacobsen, 2017; Vienna University of Technology, 2012)

culated using scaling factors as described in Equation 5 (Swanson et al., 2010).

$I_{\text {new }}=I_{0}\left(\frac{\text { Scale }_{\text {new }}}{\text { Scale }_{0}}\right)^{x_{f}}$

Within this equation, the scaling factor $x_{f}$ is 0.86 (Günther, 2014). Further factors influencing the investment costs are the building, and engineering costs, that are investment costs specific. These overhead costs are assumed to be $20 \%$ of $\mathrm{I}_{0}$ for buildings, and $15 \%$ of $\mathrm{I}_{0}$ for engineering (DACE Price Booklet, 2017) and are added on top of the investment costs. The resulting total investment costs are further referred to as I.

The capital-related annuity $A_{C}$ is calculated as follows (Becker, 2013):

$A_{C}=I^{*} \mathrm{a}$

and

$a=\frac{(1+i)^{n} * i}{(1+i)^{n}-1}$

where $n$ describes the years of operation and $i$ the interest rate. The interest rate used is 5\% (Steinmüller et al., 2014).

\subsubsection{Operational Costs}

The operational costs (OPEX) are split into the operation-related annuity $A_{0}$ and the variable costs $C_{\text {var }}$. The op- eration-related annuity $A_{o}$ includes operation, maintenance,

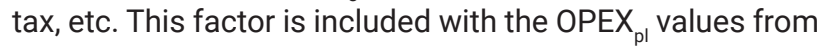
Table 3 and calculated as following:

$A_{o}=A_{c}^{*} O P E X_{p l}$

The variable costs $C_{\text {var }}$ include demand related costs like electricity, biomass, and water costs, as shown in Table 4.

Substrate cost characteristics as input factors for the analysis are averaged based on the substrates in Table 2 and data from three disposal companies operating in Austria, whereas revenues from the disposal of organic wastes depend on the type of biowaste e.g., the disposal fee for organic household waste is approximately $55 € /$ tFM (Lindorfer \& Schwarz, 2013). Substrates that contribute to the cost side are all categories for gasification as well as agricultural feedstocks like manure and straw for anaerobic digestion especially for transport expenses, while waste from food production and other organic wastes can be counted as revenues based on their representative disposal fee.

For agricultural residues, the energy density and specific methane yield determine the substrate costs e.g., substrate cost of approximately $90 € /$ tFM for straw, $35 € / t$ for grass silage; (Thrän et al., 2013).

\subsubsection{Levelized Cost of Energy}

To determine the levelized costs of the product, all

TABLE 4: Material costs for the investigated years.

\begin{tabular}{|c|c|c|c|c|c|}
\hline & & 2020 & 2030 & 2050 & Source \\
\hline Electricity & $€ / \mathrm{MWh}_{\mathrm{el}}$ & 50 & 70 & 80 & (Marktstudie zur Strompreisentwicklung 2016 - 2050, 2016) \\
\hline Water & $€ / m^{3}$ & \multicolumn{3}{|c|}{1.15} & $\begin{array}{l}\text { averaged water charges in the nine provincial capitals in Austria } \\
\text { based on data from January } 2018\end{array}$ \\
\hline Woodchips, firewood & $€ / \mathrm{MWh}_{\mathrm{th}}$ & 36 & 42 & 47 & \multirow{3}{*}{ (Landwirtschaftskammer Österreich, 2020) } \\
\hline Bark & $€ / \mathrm{MWh}_{\mathrm{th}}$ & 27 & 32 & 35 & \\
\hline Sawmill byproduct & $€ / \mathrm{MWh}_{\mathrm{th}}$ & 28 & 33 & 37 & \\
\hline
\end{tabular}


costs and revenues are related to the energy output of the process. According to VDI 2067 the total annuity A is calculated as follows:

$A=A_{P}-\left(A_{C}+A_{D}+A_{O}+A_{M}\right)$

Since the proceeds from by-product sales are treated together with the demand-related costs as actual annual costs in $C_{\text {var }}$ (instead of attributing discount rate and price changes), the annuities of proceeds $A_{P}$ and demands $A_{D}$ can be omitted in Equation 7. Same accounts for the annuity of additional costs $A_{M}$ representing the overhead costs for buildings and engineering, which are already included in $A_{C}$. Thus, Equation 7 is simplified to:

$A=A_{C}+A_{O}$

With the annuity and demand related variable costs, one can calculate the LCOE as described in Equation 9, with $P_{S N G, n}$ as the annual methane production (Böhm et al., 2020; Parra et al., 2017).

$L C O E=\frac{-A+\sum_{n} C_{v a r, n}}{\sum_{n} P_{S N G, n}}$

\subsection{Theoretical Merit Order}

In the energy economy, a theoretical merit order is a statistical tool to rank energy potentials from different sources by their costs. It is most commonly used in the electricity market to determine which power stations should run at what time to fulfill electricity demand with the lowest overall generation costs. The overall result is a ranking of technologies and resources by their potential and price, starting with the least expensive and ending with the most expensive (Cludius et al., 2014; Luňáčková et al., 2017; Sensfuß et al., 2008). Therefore, it is a popular method in many papers that focus on potential, costs, or both in terms of energy generation.

In this paper, a theoretical merit order is used to compare the costs of the potentials for biomass gasification, anaerobic digestion, and power-to-gas. This merit order should allow for the quantification of which potential should be used first to meet demands.

\section{RESULTS AND DISCUSSION}

As part of this work, the described system was analyzed with a potential analysis and technoeconomic analysis approach. This permits us to describe the potential of renewable gas production from organic waste and biomass in a technology-coupled approach.

\subsection{Anaerobic Digestion}

For 2020 the theoretical potential from all residue flows in Austria results in 1,582 Mio. $\mathrm{Nm}^{3}$ biomethane from anaerobic digestion per year. This value is reduced to 1,533 Mio. $\mathrm{Nm}^{3}$ biomethane per year till 2050 due to the reduction of agricultural waste streams that current developments show. However, these values only represent the theoretical potential. More interesting is the technical potential, since it shows the potential cap of gatherable biomethane with available technologies.

This process can produce about 650 million $\mathrm{Nm}^{3}$ of biomethane per year in 2020, a value that will decrease slightly by 2050 to about 600 million $\mathrm{Nm}^{3}$ of biomethane. Most of it can be produced from agricultural residue and waste from food production. Furthermore, the calculations revealed that up to 450 million $\mathrm{Nm}^{3} \mathrm{CO}_{2}$ from biogas cleaning would be available for SNG production via powerto-gas. More detailed information on the calculations for the potential categories is provided in the supplementary material.

To develop this potential, facilities for this purpose must be constructed. Figure 3 illustrates a possible expansion scenario to tap into the full potential by 2050 . In the beginning, many small biomethane plants will be expanded and will later be partially replaced by or upgraded into plants with much higher production volumes. In total, 259 plants will need to operate in 2050 to fully exploit the potential.

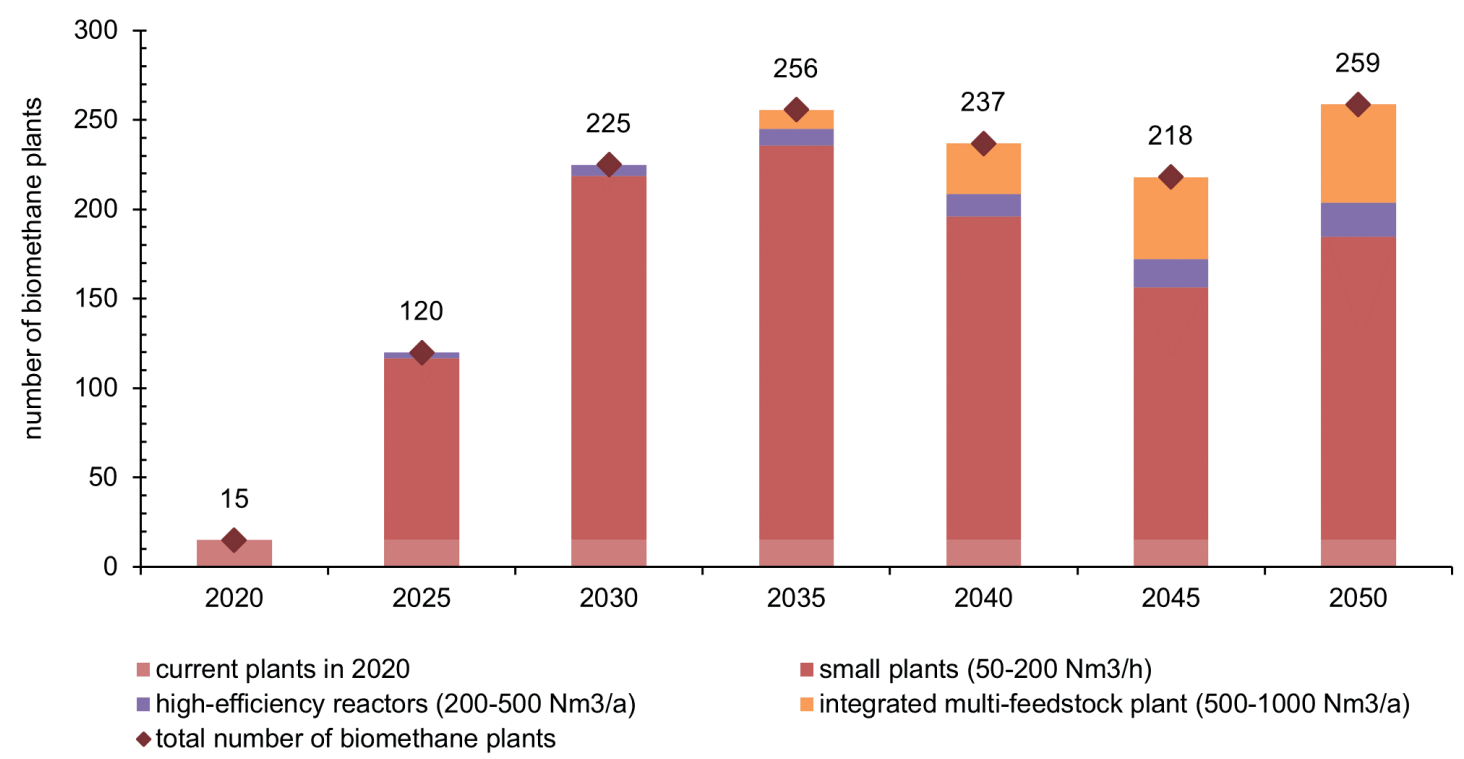

FIGURE 3: Expansion scenario for biomethane plants between 2020 and 2050. 
However, the technical potential only includes current technical possibilities in gathering waste and not future developments. In the case of cuttings from bushes, grass, and trees and biowaste from households, future technologies will likely not substantially increase salvage rates. This differs for categories such as garden composting and straw. In terms of garden composting, the value of $0 \%$ of technical potential on the theoretical one will likely not increase, but regulative changes may move this category to biowaste from households, which already has a high technical potential. The idea is that people will stop composting waste privately and start to treat this waste like biowaste from households and therefore "activate" this category for anaerobic digestion. For straw, a higher gathering rate from fields may be possible with better developed tools for agriculture.

In the first stage of expansion (from today through 2030), new plants for the utilization of biogenic waste from the food industry, biowaste, food waste in residual waste, and sewage sludge will contribute to increasing resource efficiency. This prioritization was used since these categories are easily fermentable, more liquid biogenic residues in which they are easier for energetically utilization via anaerobic decomposition. Under this assumption, around 226 million $\mathrm{Nm}^{3} / \mathrm{a}$ of the technical methane potential can be realized in 2030 . This corresponds to around $37 \%$ of the total potential.

In the second expansion stage (2030-2050), biogas will be produced from the more difficult-to-use residues from animal and plant production, and more synthetic methane will be produced. Further potentials, such as use of biogenic material from home garden composting, require a more in-depth system conversion and expansion of existing residue logistics and could therefore be realized from 2030 to 2050 at the earliest.

However, there are technical issues with this form of renewable energy, in addition to activating waste streams to increase the technical potential and the expansion of plants. The costs are another point that should be evaluated. As demonstrated in Figure 4, the costs for produc- ing biomethane from organic waste are highly dependent on the plant size. With about $9 €$-cent/kWh in 2020, small plants with a capacity of 50 to $200 \mathrm{Nm}^{3} / \mathrm{h}$ are more cost intensive in comparison to high-efficiency reactors with a 200 to $500 \mathrm{Nm}^{3} / \mathrm{h}$ capacity ( 7 €-cent/kWh in 2020) and integrated multifeedstock plants with a capacity of 500 to $1,000 \mathrm{Nm}^{3} / \mathrm{h}$ ( $\sim €$-cent/kWh in 2020). The major share of the costs comes from building the biogas plant itself $(62 \%$ to $64 \%$ ). Another major cost component is the $\mathrm{CH}_{4}$ processing that is necessary for feeding into the gas grid (25\% to $27 \%$ ), while substrate input has no significant influence on the cost. These costs are expected to decrease to 5 to 6 €-cent/kWh by 2050.

These costs as shown in Figure 4 are in a good range compared to other studies. (Nelissen et al., 2020) analyzed many studies that focused on anaerobic digestion and gasification of biomass. Within the study it was shown that LCOE for anaerobic digestion are in a range of 5.7 and $14.1 €$-cent per $\mathrm{kWh}$. This range is due to the wide variety of substrates and plant technologies (pretreatment, fermentation and upgrading) taken into account. The values are comparable with other analyses for central Europe e.g. (Kost et al., 2018)5.4 - 6.9 or (European Commission, 2020) 4.1 - $8.0 €$-cent per kWh recalculated from Levelized cost of electricity production.

Another issue is that the utilization of biogenic waste in anaerobic digestion plants can only be successfully established in the future if nutrient cycles are successfully closed at the same time. Anaerobic digestion is followed by composting of the digestate, and the resulting compost and the nutrients it contains are preserved for agriculture, horticulture, or private gardens. The liquid digestate can be used directly in agriculture. This could further increase the rentability of such plants, while also solving the issue of energy-intensive and resource-depleting fertilizer production.

\subsection{Power-to-Gas}

The $\mathrm{CO}_{2}$ from biogas cleaning (see Section 3.1) is a suitable source for power-to-X applications (Götz et al., 2016;

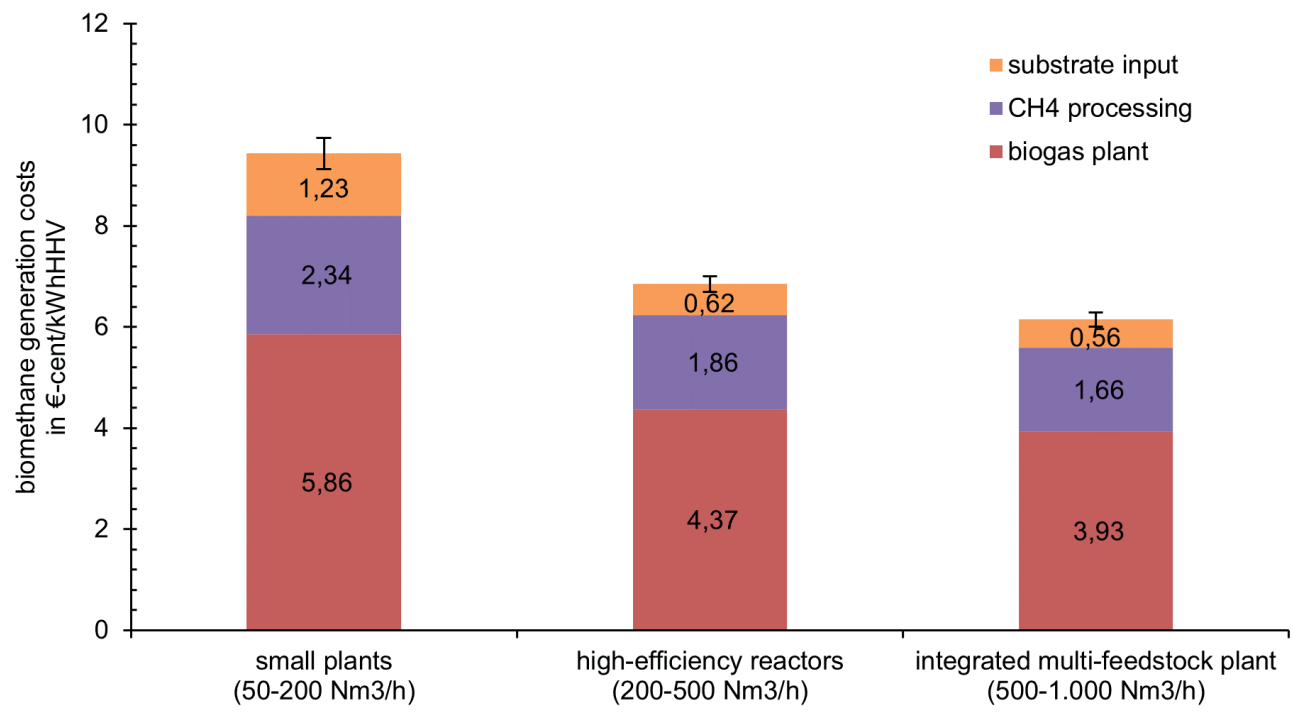

FIGURE 4: Costs for biomethane production via anaerobic digestion in 2020. 
Rodin et al., 2020). Up to 330 million Nm³ SNG per year may be produced by using the technically available $\mathrm{CO}_{2}$ from the biogas upgrading process. To provide sufficient $\mathrm{H}_{2}$ for the methanation reaction, about 160 million $\mathrm{Nm}^{3} \mathrm{H}_{2}$ per year would be necessary, which correlates to about $9 \mathrm{GWh}$ of electricity demand per year for the electrolyzer unit.

As illustrated in Figure 5, to provide sufficient hydrogen for methanation, 178 plants, mainly small plants in the size of 0.5 to $1 \mathrm{MW}$, must be built. This number must increase to 870 by 2050 . Since the number of power-to-gas plants is much higher than the number of biomethane plants, a decentralized approach is possible. All values are based on an average operation time of 3,500 hours per year since this value would allow for cost-effective operation and fluctuations of the electricity grid could be used to produce hydrogen at peak times (Gorre et al., 2019).

In terms of specific costs, due to economies of scale and learning curve effects, significant cost reduction potentials likely exist for plant-specific investment costs. The CAPEX values in Section 2.3 illustrate this point.
Therefore, the investment costs of the LCOE for the production of SNG via power-to-gas shrink over time (see Figure 6). In addition, the operational costs in Figure 6 decrease over time since this category is mainly influenced by investment costs related to operational costs such as insurance, maintenance, and administration. For electricity-related costs (electricity costs and grid fees), the cost reduction is not as high as for investment-related costs. This effect stems from the fact that the overall electricity price is expected to rise by 2050 (enervis energy advisor $\mathrm{GmbH}, 2016)$. However, since the plant is expected to be operated at peak load hours (about 3,500 h/a), when electricity-related costs are low, a small reduction effect for electricity-related costs was investigated. In total, for SNG, costs are expected to decline from $29.3 €$-cent per kWh in 2020 to 10.9 €-cent per kWh by 2050 (see Figure 6). However, under consideration of potential revenues from selling byproduct oxygen and heat, effective production costs could be reduced to 24.8 and $6.5 €$-cent/kWh, respectively.

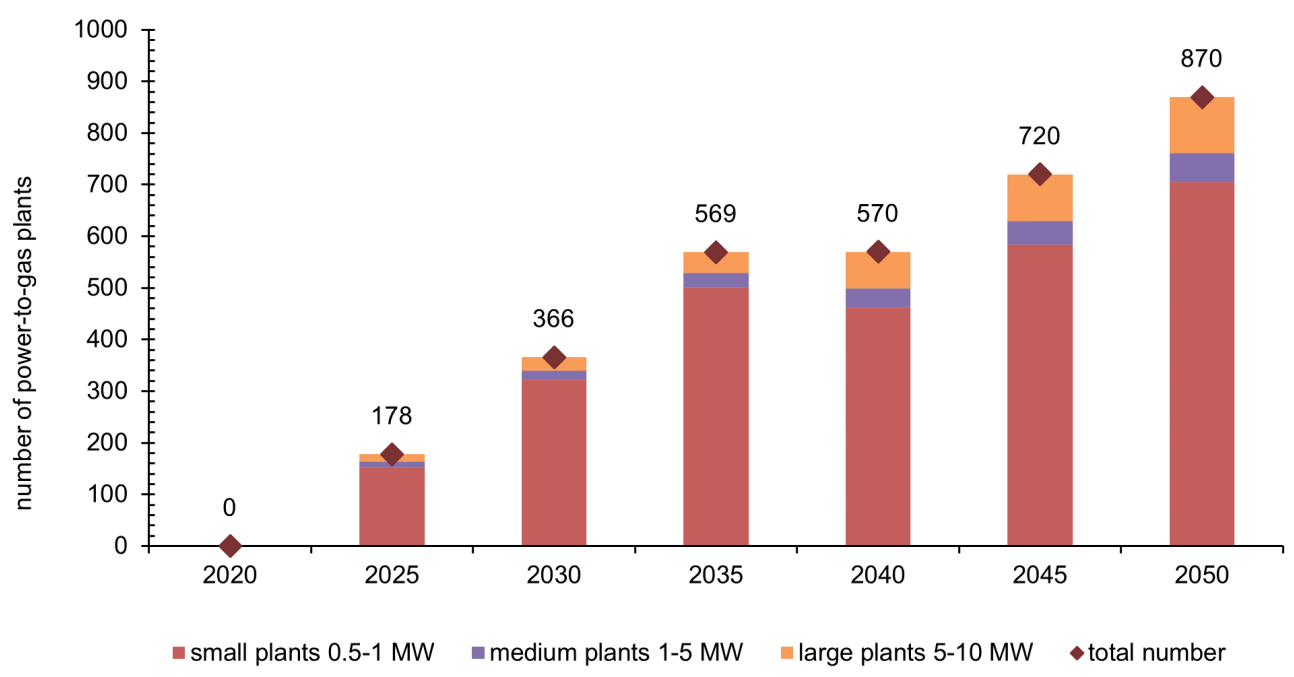

FIGURE 5: Expansion Scenario for Power-to-Gas Plants by 2050.

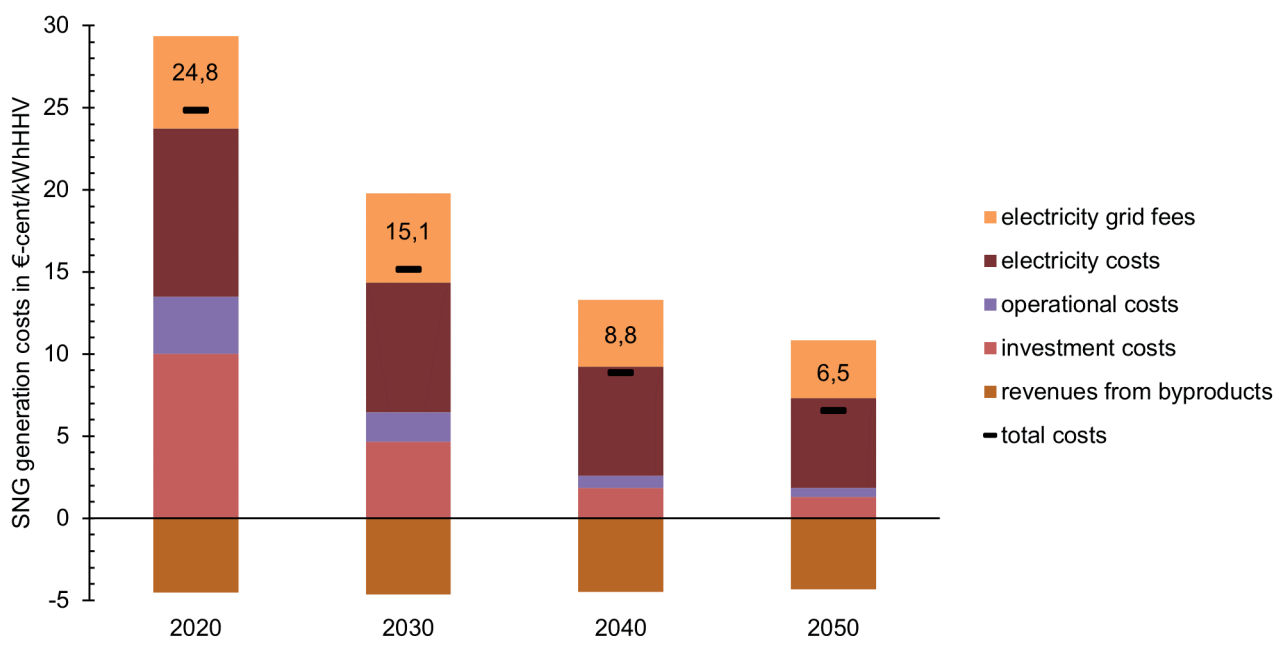

FIGURE 6: Synthetic natural gas generation costs for electrolyzers with 10-50 MWel. 
These cost ranges are comparable to the results gained by previous studies on power-to-gas production costs. (Gorre et al., 2020) calculated SNG production costs of 4.7 to $21 €$-cent/kWh by optimizing hydrogen storage and methanation capacities. The costs evaluated by (Böhm et al., 2020) suggest that hydrogen could be produced at about $5 €$-cent/kWh in 2050, presuming electricity costs similar to today. However, due to the strong dependencies of the power-to-gas process on external conditions, such as electricity costs, mode of operation, storage capacities, etc. as shown by (Gorre et al., 2019) a direct comparison of different applications is hardly possible.

The long-term use of existing gas infrastructure will depend heavily on the degree of integration of renewable gases. Thus, overall climate and energy policy objectives will also be supported by the existing gas infrastructure, which could ensure the long-term use of this infrastructure. As a consequence, enormous investments that have not yet been depreciated can still be realized, and massive opportunity costs or investments are not necessary; such investments would have a significant negative impact on the national economy, with the exception of an interim investment impulse in alternative strategies. "Greening the gas" through hydrogen and synthetic methane from renewable energy sources as well as through biomethane from biogenic residues is thus a main component of the need for the sustainable further development of the energy system (Tichler \& Zauner, 2018).

\subsection{Biomass Gasification}

In the course of the assessment of the potential for the production of green methane via the thermochemical conversion of biomass with a high lignin content, much higher technical potentials were identified than for biomethane production. As seen in Figure 7, the potential in 2030 amounts to about 3,300 million $\mathrm{Nm}^{3}$ per year and increases to just under 4,000 million $\mathrm{Nm}^{3}$ per year by 2050 .

To exploit the full biomass gasification potential, 163 plants must be commissioned by 2050 (see Figure 8 ). The majority of these are plants should have a capacity of 35 MW. The other plants can be operated with up to $100 \mathrm{MW}$ and will, despite their smaller numbers, produce the majority of bio SNG from biomass by 2050 .

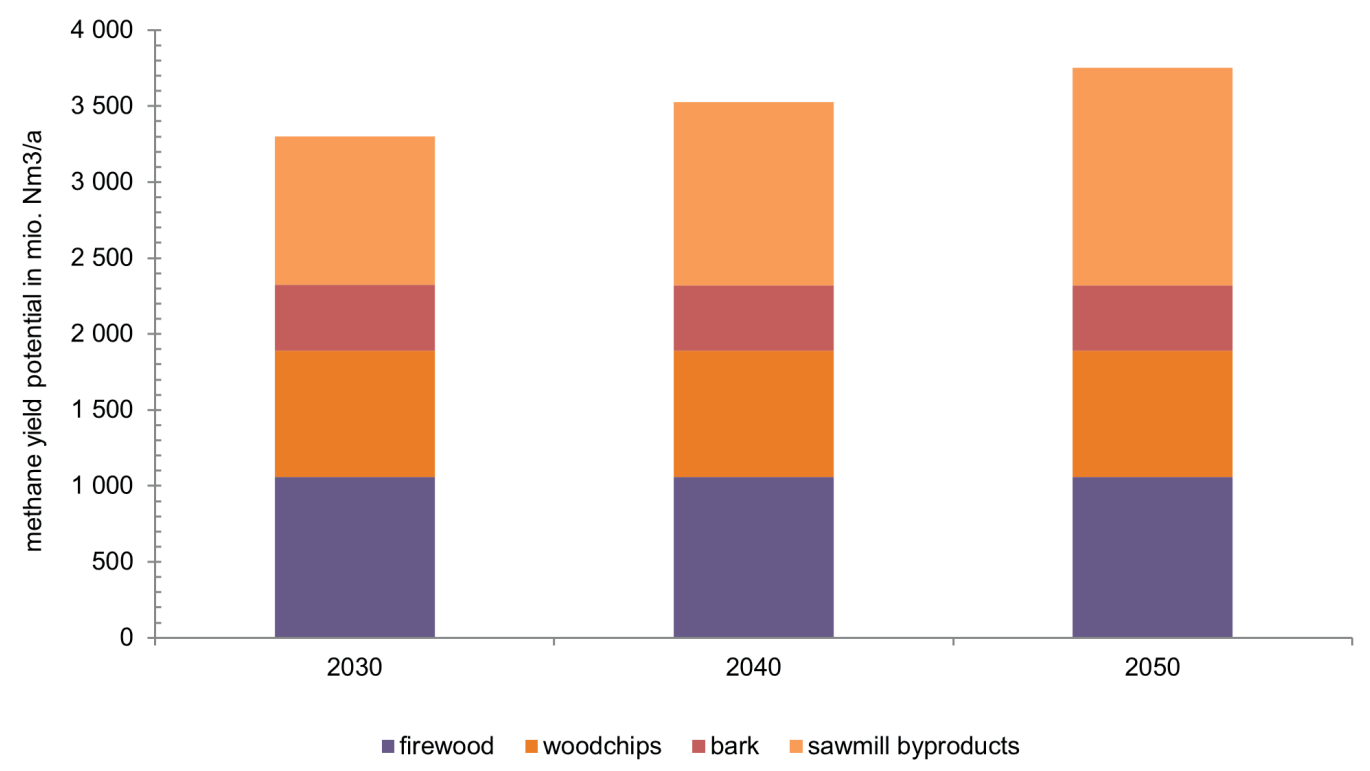

FIGURE 7: Potential for green methane from biomass gasification between 2030 and 2050.

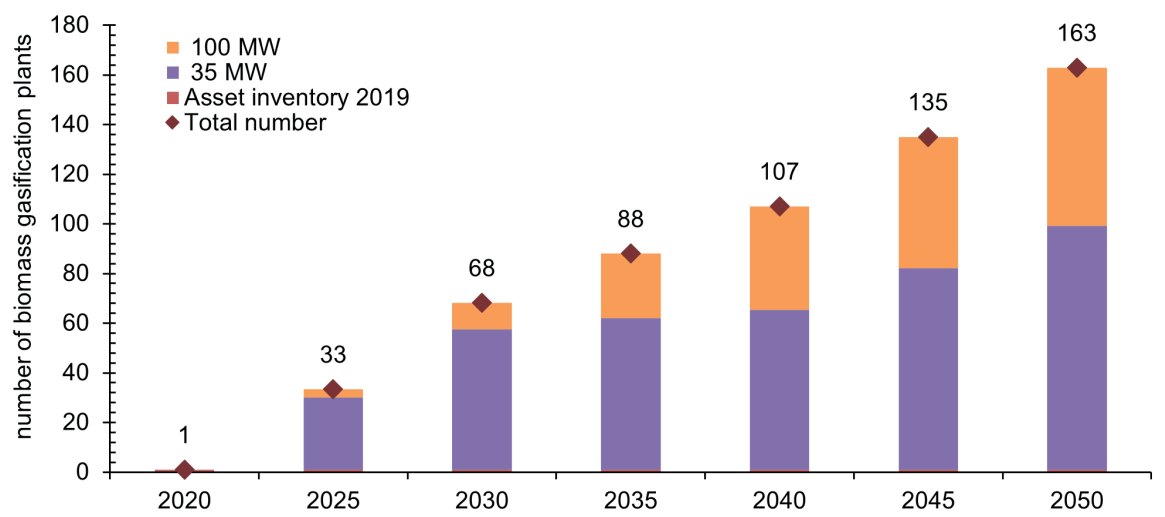

FIGURE 8: Expansion scenario for biomass gasification plants between 2020 and 2050. 
As shown within this section, the power-to-gas plants outnumber the gasification and biomethane plants. The reason for the outnumbering of the power-to-gas plants in comparison to the gasification or biomethane plants originate from the different plant capacities. While the investigated gasification system is defined with a scaling of up to $100 \mathrm{MW}$ based on the complex feedstock handling and gas cleaning, the investigated power-to-gas plants only reach up to a maximum of $10 \mathrm{MW}$ per plant. Therefore, one power-to-gas plant can methanate the $\mathrm{CO}_{2}$ from more than one biomethane plant (that can reach up to $1 \mathrm{MW}$ within the investigated scope) but only a small percentage of the $\mathrm{CO}_{2}$ from the $35 \mathrm{MW}$ and $100 \mathrm{MW}$ gasification plants.

To minimize transport costs and losses, a decentralized approach would be favorable, were several powerto-gas, biomethane and gasification plants are connected within a short geographical radius.

From the cost perspective, the $100 \mathrm{MW}$ scale plant was specifically investigated. The results suggest that investment costs should decrease from $4.1 €$-cent/kWh in 2020 to $3.2 €$-cent/kWh by 2050 (see Table 5). Furthermore, the operation, maintenance, and other costs will decrease from $0.8 €$-cent/kWh in 2050 to $0.7 €$-cent/kWh by 2050 . However, the most significant cost factor is the fuel price. Woodchips are particularly expensive, with a cost increase from $5.2 €$-cent/kWh in 2050 to $6.8 €$-cent/kWh by 2050 . Bark (3.9 €-cent/kWh in 2020 and $5.1 €$-cent/kWh in 2050), as well as sawmill byproducts (4.1€-cent/kWh in 2020 and $5.4 €$-cent/kWh in 2050), have increasing prices as well. Nevertheless, both bark and sawmill byproducts are less expensive than woodchips.

The costs are in a good range to other studies according to a review by (Nelissen et al., 2020). Within the study, LCOE for methane from gasification was given in a range of 6.9 and $17.71 €$-cent per kWh for current technologies. This large range comes from the different plant sizes, that reaches up to $150 \mathrm{MW}$ within the analyzed studies, and the different substrates. For future costs only one study is mentioned within the review. This study by (van Melle et al., 2018) shows LCOE of $3.7 €$-cent per kWh for a about 50 MW plant. However, this low costs mainly occur from the used assumptions for the fuels. The fuels are mainly lowcost biomass including some substrate categories that in this study are used for anaerobic digestion. Furthermore, the costs for the fuels are assumed much lower in comparison to the values in this work. Within (van Melle et al., 2018) the fuel costs are not in detail mentioned experts assumption. Beside this methodological difference, geo-

TABLE 5: Specific costs for the production of $1 \mathrm{kWh}$ of synthetic natural gas with biomass gasification for woodchips, bark, and sawmill byproducts as fuel - $100 \mathrm{MW}$ plant.

\begin{tabular}{l|c:c|c}
\hline In €-cent per kWh SNG & $\mathbf{2 0 2 0}$ & $\mathbf{2 0 3 0}$ & $\mathbf{2 0 5 0}$ \\
\hline Investment costs & 4.1 & 3.8 & 3.2 \\
\hdashline Operation, maintenance, and other fuel & 0.8 & 0.8 & 0.7 \\
\hdashline Woodchips & 5.2 & 6.1 & 6.8 \\
\hdashline Bark & 3.9 & 4.6 & 5.1 \\
\hdashline Sawmill byproducts & 4.1 & 4.8 & 5.4 \\
\hline
\end{tabular}

graphical factors etc. further have a large influence on the biomass prices. According to (Kraussler et al., 2018), the plant size on the other hand does not have a large cost reducing factor above $40 \mathrm{MW}$.

\subsection{Merit Order}

In total, up to 60 TWh of green gas can be produced from these three categories of potential as technical potential. Within the technoeconomic analysis, the costs of such an expansion of green gases were considered. Figure 9 shows the time course of production costs between 2030 and 2050; these include not only investment costs but also operating costs. For the three categories of biomass gasification (only the fuels, not the plants, being changed), costs remain relatively constant, ranging from 9.0 to $10.7 €$-cent/ kWh depending on the fuel and year. For SNG from powerto-gas, production costs will presumably decrease from an initial $10.8 €$-cent/kWh in 2030 to $6.5 €$-cent/kWh by 2050 . For anaerobic digestion, the average production costs will likely decrease from 7.9 to $5.4 €$-cent/kWh between 2030 and 2050.

Based on the production costs and potentials, forming a theoretical merit order curve was possible, as described in section 0. Figure 10 shows an example for 2030. The figure demonstrates that the biomethane potential from anaerobic digestion should be used first, followed by biomass gasification and power-to-gas. However, methane from power-to-gas is becoming increasingly important and will have similar production costs in 2050 as biomethane from anaerobic conversion.

In terms of investment costs, with the calculated costs and expansion scenarios for developing 17 TWh of biomethane from anaerobic fermentation, $€ 3.3$ billion would have to be invested by 2050. To develop the 52 TWh and 62 TWh gasification plants, $€ 2.4$ billion and $€ 5$. 7 billion, respectively, would have to be invested by 2050 .

Overall, the prime costs for green gas are higher than the average prices of natural gas (reference year 2019) for households ( $5 €$-cent/kWh) and for industry (2.5 €-cent/ kWh; (eurostat, 2020). As a result, the promotion of green gas leads to additional costs for utilities.

\section{CONCLUSIONS AND OUTLOOK}

Natural gas is an energy source that currently plays an important role in many areas. Especially in some applications, it is costly or technologically complex to replace due to its technical and economic properties. Therefore, many actors are making an effort to replace the current fossil energy carriers of natural gas with gas from renewable sources. At the same time, assumptions differ regarding the domestic supply of renewable gases that will be available for these applications. The availability of renewable gas was determined in an Austrian case study based on the technical quantities of methane that can be produced from biogenic residues. The feasible quantities were estimated for 2040 with the assumption that value chains for the use of biogenic residues can be redesigned by then to maximize availabilities.

The potential analysis demonstrated a high potential 


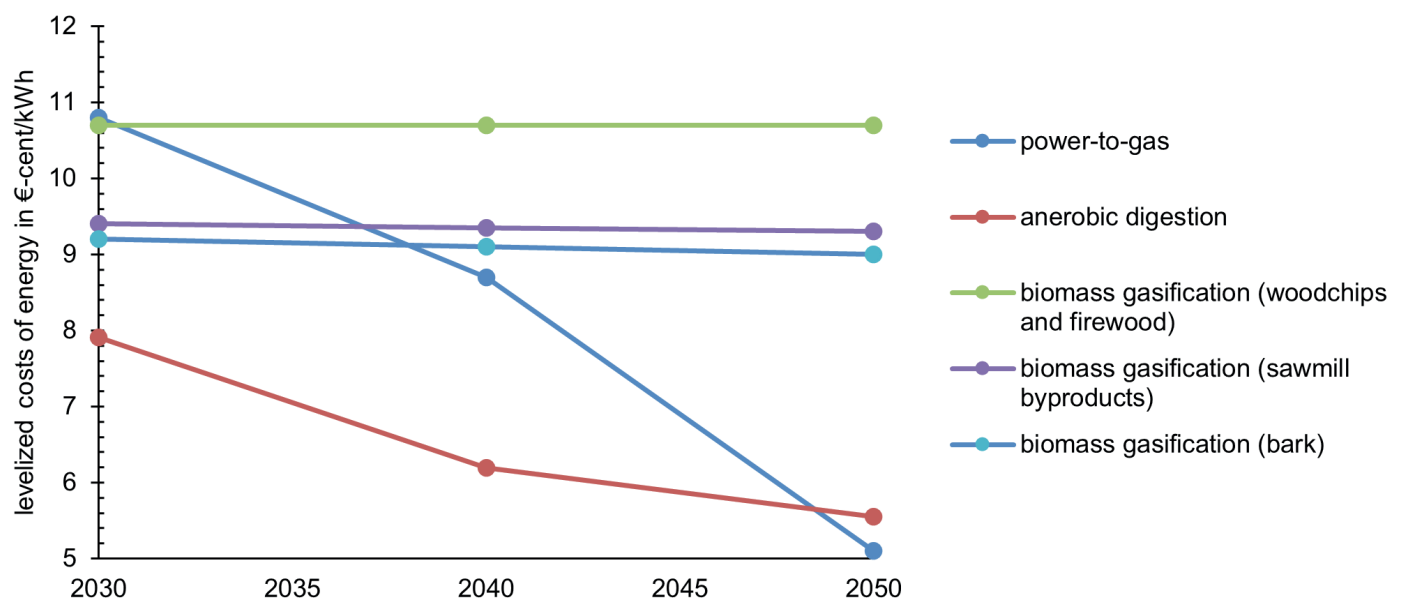

FIGURE 9: Timeline of the production costs for green gases.

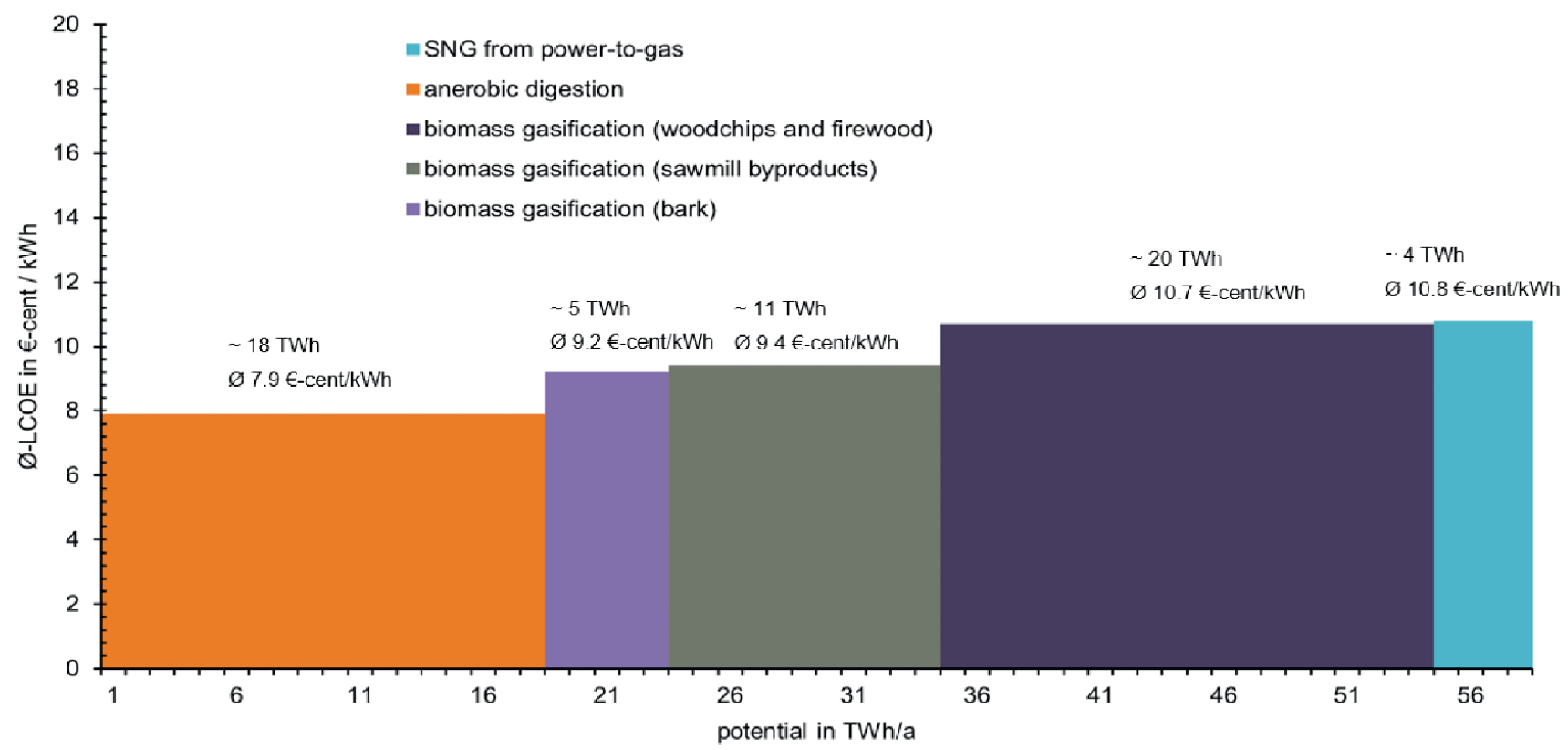

FIGURE 10: Theoretical merit order curve of the potential for 2030.

for renewable methane, with a production capacity of more than 50 TWh in 2030 increasing to more than 60 TWh in 2050 throughout all biogenic residue categories, synthetic renewable gas potentials, and conversion technologies. This could technically meet the Austrian natural gas demand by more than $50 \%$. For the potential categories, the analysis outlined that biomass gasification of firewood and woodchips (e.g., from storm-damaged timber) and anaerobic digestion of the various streams provide the two largest quantitative contributions to the overall potential, while SNG from power-to-gas utilizing $\mathrm{CO}_{2}$ from anerobic digestion contributes the smallest amount. To increase the potential, future research and legislative actions need to focus on increasing the accessibility of the technical potential. Especially from an ecological point of view, the addressed residues (e.g., from wood) can play an important role as a primary raw material, and their use could reduce fossil energy and greenhouse gas emissions in many sec- tors such as the paper and pulp industry or construction. Competing uses are to be predicted and, at any rate, prevented when a technical potential is realized.

However, even though renewable methane has a large energy potential, another point that must be critically reviewed is economic performance. From a technoeconomic perspective, the results revealed that the two categories with the highest potential are on the opposite ends of the merit order. While anerobic digestion was expected to be the least cost-intensive renewable methane source of the study with about $7.9 €$-cent per kWh, biomass gasification of firewood and woodchips has one of the highest costs of $10.7 €$-cent per kWh. However, even anaerobic digestion resulted in much higher costs compared with the current industrial and household price for natural gas. Therefore, future work should focus on utilizing most byproducts of the various technologies to increase side revenues, which then should make the technologies more cost effective. 
Furthermore, the framework conditions should change in an attempt to eliminate the cost difference between renewable and fossil energy carriers.

\section{ACKNOWLEDGMENTS}

This work was supported by the Austrian Research Promotion Agency [grant number 864876-ReNOx 2.0] and the Energieinstitut an der Johannes Kepler Universität Linz.

\section{REFERENCES}

Alibardi, L., \& Cossu, R. 2015. Composition variability of the organic fraction of municipal solid waste and effects on hydrogen and methane production potentials. Waste Manag, 36, 147-155. doi: https://doi.org/10.1016/j.wasman.2014.11.019

Batidzirai, B., Smeets, E. M. W., \& Faaij, A. P. C. 2012. Harmonising bioenergy resource potentials-Methodological lessons from review of state of the art bioenergy potential assessments. Renewable \& Sustainable Energy Reviews, 16(9), 6598-6630. doi: https://doi. org/10.1016/j.rser.2012.09.002

Becker, H. P. 2013. Investition und Finanzierung (Investment and financing). Wiesbaden: Springer. ISBN: 978-3-658-00378-4

Birol, F. 2020. Energy technology perspectives. cited in https://www. iea.org/reports/energy-technology-perspectives-2020 consulted on the 09.09.2021

Böhm, H., Zauner, A., Rosenfeld, D. C., \& Tichler, R. 2020. Projecting cost development for future large-scale power-to-gas implementations. Applied Energy, 264, 114780. doi: https://doi.org/10.1016/j.apenergy.2020.114780

Boldrin, A., Baral, K. R., Fitamo, T., Vazifehkhoran, A. H., Jensen, I. G., Kjaergaard, I., Lyng, K. A., Nguyen, Q. V., Nielsen, L. S., \& Triolo, J. M. 2016. Optimised biogas production from the co-digestion of sugar beet with pig slurry: Integrating energy, GHG and economic accounting. Energy, 112, 606-617. doi: https://doi.org/10.1016/j. energy.2016.06.068

British Petroleum p.l.c. 2019. BP statistical review of world energy. cited in https://www.bp.com/content/dam/bp/business-sites/ en/global/corporate/pdfs/energy-economics/statistical-review/ bp-stats-review-2019-full-report.pdf consulted on the 09.09.2021

Brosowski, A., Adler, P., Erdmann, G., Thrän, D., Mantau, U., \& Blanke, C. 2015. Biomassepotenziale von Rest-und Abfallstoffen-Status quo in Deutschland (Biomass potential of residue and waste streams - status quo in Germany). cited in https://mediathek.fnr. de/band-36-biomassepotenziale-von-rest-und-abfallstoffen.html consulted on the 09.09.2021

Bundesanstalt für Agrarwirtschaft. 2016. Grüner Bericht 2016 (Green report 2016). cited in https://gruenerbericht.at/cm4/jdownload/ download/2-gr-bericht-terreich/1650-gb2016 consulted on the 03.09.2019

Bundesforschungszentrum für Wald. 2013. Wald im Fokus (Forrest in focus). cited in https://www.google.com/ $u r l$ ? $s a=t \& r c t=j \& q=\& e s r c=s \& s o u r c e=w e b \& c d=\& v e d=2 a-$ hUKEwjJ 1 bbPifLyAhUrsaQKHUm8Bi4QFnoECAUQAQ\&url=http\%3A\%2F\%2Fwww.bfw.ac.at\%2Fwebshop\%2Findex. php\%3Fcontroller\%3Dattachment\%26id_attachment\%3D151\&us$\mathrm{g}=\mathrm{AOvVaw} 2 \mathrm{KuXFKU5pkYNC4re2SqqfR}$ consulted on the 09.09.2021

Bundesministerium Nachhaltigkeit und Tourismus. 2019. Die Bestandsaufnahme der Abfallwirtschaft in Österreich - Statusbericht 2019 (The inventory of waste management in Austria - status report 2019). cited in https://www.arge.at/wp-content/uploads/2019/06/ Die_Bestandsaufnahme_der_Abfallwirtschaft_in_\%c3\%96sterreich_web.pdf consulted on the 03.09.2019

Burg, V., Bowman, G., Haubensak, M., Baier, U., \& Thees, O. 2018. Valorization of an untapped resource: energy and greenhouse gas emissions benefits of converting manure to biogas through anaerobic digestion. Resources Conservation and Recycling, 136, 53-62. doi: https://doi.org/10.1016/j.resconrec.2018.04.004

Buttler, A., \& Spliethoff, H. 2018. Current status of water electrolysis for energy storage, grid balancing and sector coupling via powerto-gas and power-to-liquids: A review. Renewable \& Sustainable Energy Reviews, 82, 2440-2454. doi: https://doi.org/10.1016/j. rser.2017.09.003
Cludius, J., Hermann, H., Matthes, F. C., \& Graichen, V. 2014. The merit order effect of wind and photovoltaic electricity generation in Germany 2008-2016: Estimation and distributional implications. Energy Economics, 44, 302-313. doi: https://doi.org/10.1016/j. eneco.2014.04.020

DACE Cost and Value. 2017. DACE price booklet (32 ed.). Nijkerk: DACE Cost and Value. ISBN: 9463460039

Dißauer, C., Rehling, B., \& Strasser, C. 2019. Machbarkeitsuntersuchung Methan aus Biomasse (Feasibility study methane from biomass). cited in https://www.gruenes-gas.at/assets/Uploads/BioEenergy2020+_Machbarkeitsuntersuchung_Methan_aus_Biomasse.pdf consulted on the 01.03.2020

enervis energy advisor $\mathrm{GmbH}$. 2016. Marketstudie zur Strompreisentwicklung 2016-2050 (Marketstudy on the electricity price development 2016-2050). cited in https://enervis.de/leistung/european-power-market-outlook/ consulted on the 09.09.2021

Erler, R., Hüttenrauch, J., Schuhmann, E., Graf, F., Kiefer, J., Ball, T., Fischer, T., Kappertsbusch, V., \& Dresen, B. 2013. Potenzialstudie zur nachhaltigen Erzeugung und Einspeisung gasförmiger, regenerativer Energieträger in Deutschland (Biogasatlas) (Potentialstudy on the sustainable production and feed in of gaseous, renewable energy carriers in Germany (Biogas atlas)). cited in https://www. dvgw.de/medien/dvgw/forschung/berichte/gw2_01_10.pdf consulted on the 09.09.2021

European Commission. 2011. A Roadmap for moving to a competitive low carbon economy in 2050. cited in https://eur-lex.europa.eu/ LexUriServ/LexUriServ.do?uri=COM:2011:0112:FIN:EN:PDF consulted on the 09.09.2021

European Commission. 2019. The European green deal. cited in https://eur-lex.europa.eu/legal-content/EN/TXT/PDF/?uri=CELEX:52019DC0640\&from=EN consulted on the 09.09.2021

European Commission. 2020. Final Report Cost of Energy (LCOE) Energy costs, taxes and the impact of government interventions on investments. cited in https://op.europa.eu/en/publication-detail/-/publication/76c57f2f-174c-11eb-b57e-01aa75ed71a1/language-en consulted on the 09.09.2021

eurostat. (2020). Natural gas price statistics. cited in https://ec.europa.eu/eurostat/statistics-explained/index.php/Natural_gas_ price_statistics consulted on the 24.02.2021

FNR. 2013. Leitfaden Biogas: Von der Gewinnung zur Nutzung (Guideline biogas: from extraction to use). cited in https://www.fnr.de/ fileadmin/allgemein/pdf/broschueren/Leitfaden_Biogas_web_ V01.pdf consulted on the 09.09.2021

Gao, Y., Gao, X., \& Zhang, X. H. 2017. The 2 degrees C global temperature target and the evolution of the long-term goal of addressing climate change - from the United Nations framework convention on climate change to the Paris agreement. Engineering, 3(2), 272278. doi: https://doi.org/10.1016/J.Eng.2017.01.022

German Advisory Council on Global Change. 2009. Welt im Wandel: Zukunftsfähige Bioenergie und nachhaltige Landnutzung (Future bioenergy and sustainable land use): WBGU. ISBN: 978-3-93619121-9

Gorre, J., Ortloff, F., \& van Leeuwen, C. 2019. Production costs for synthetic methane in 2030 and 2050 of an optimized Power-to-Gas plant with intermediate hydrogen storage. Applied Energy, 253, 113594. doi: https://doi.org/10.1016/j.apenergy.2019.113594

Gorre, J., Ruoss, F., Karjunen, H., Schaffert, J., \& Tynjala, T. 2020. Cost benefits of optimizing hydrogen storage and methanation capacities for Power-to-Gas plants in dynamic operation. Applied Energy, 257, 113967. doi: https://doi.org/10.1016/j.apenergy.2019.113967

Götz, M., Lefebvre, J., Mörs, F., McDaniel Koch, A., Graf, F., Bajohr, S. Reimert, R., \& Kolb, T. 2016. Renewable Power-to-Gas: A technological and economic review. Renewable Energy, 85, 1371-1390. doi: https://doi.org/10.1016/j.renene.2015.07.066

Günther, T. 2014. Entwicklung einer Bewertungsmethodik zur Standortplanung und Dimensionierung von Wasserstoffanlagen (Development of an evaluation methodology for site planning and dimensioning of hydrogen plants). (Dr.Ing.). Brandenburgischen Technischen Universität Cottbus (Brandenburg University of Technology - Cottbus), cited in https://opus4.kobv.de/opus4-btu/frontdoor/index/index/docld/2984 consulted on the 10.09.2021

Hofbauer, H., Rauch, R., Bosch, K., Koch, R., \& Aichernig, C. (2002). Biomass CHP plant Guessing-a success story. Paper presented at the Expert meeting on pyrolysis and gasification of biomass and waste. cited in https://citeseerx.ist.psu.edu/viewdoc/download?doi=10.1.1.607.9078\&rep=rep1\&type=pdf consulted on the 10.09.2021 
Kampman, B., Leguijt, C., Scholten, T., Tallat-Kelpsaite, J., Brückmann, R., Maroulis, G., Lesschen, J., Meesters, K., Sikirica, N., \& Elbersen, B. 2020. Optimal use of biogas from waste streams. cited in https://ec.europa.eu/energy/sites/ener/files/documents/ce_ delft_3g84_biogas_beyond_2020_final_report.pdf consulted on the 09.09.2021

Kern, S., Pfeifer, C. \& Hofbauer, H. 2013. Gasification of wood in a dual fluidized bed gasifier: Influence of fuel feeding on process performance. Chemical Engineering Science, 90, 284-298. doi: https:// doi.org/10.1016/j.ces.2012.12.044

Kompost \& Biogas Verband Österreich. (2021). Biomethan in Österreich (Biomethane in Austria). cited in https://www.kompost-biogas. info/biogas/biomethan/biomethan-in-oesterreich/ consulted on the 23.02.2021

Kost, C., Shammugam, S., Jülch, V., Huyen-Tran, N., \& Schlegl, T. 2018. Levelized cost of electricity renewable energy technologies. cited in https://www.ise.fraunhofer.de/content/dam/ise/en/documents/publications/studies/EN2018_Fraunhofer-ISE_LCOE_Renewable_Energy_Technologies.pdf consulted on the 09.09.2021

Kotowicz, J., Węcel, D., \& Jurczyk, M. 2018. Analysis of component operation in power-to-gas-to-power installations. Applied Energy, 216, 45-59. doi: https://doi.org/10.1016/j.apenergy.2018.02.050

Kraussler, M., Pontzen, F., Muller-Hagedorn, M., Nenning, L., Luisser, M., \& Hofbauer, H. 2018. Techno-economic assessment of biomass-based natural gas substitutes against the background of the EU 2018 renewable energy directive. Biomass Conversion and Biorefinery, 8(4), 935-944. doi: https://doi.org/10.1007/s13399018-0333-7

KTBL. 2008. Betriebsplanung Landwirtschaft 2008/09: Daten zu Schlachtabfällen und Schweinemist aus Genesys-Merkblatt M101 - Biogasausbeute von Hofdüngern und Co-Substraten (Farm planning for agriculture 2008/09: Data on slaughterhouse waste and pig manure from Genesys leaflet M101 - Biogas yield from farm manure and co-substrates). cited in https://www.ktbl.de/ fileadmin/user_upload/Allgemeines/Download/Datensammlung/P_19491-small.pdf consulted on the 09.09.2021

Kuo, J., \& Dow, J. 2017. Biogas production from anaerobic digestion of food waste and relevant air quality implications. J Air Waste Manag Assoc, 67(9), 1000-1011. doi: https://doi.org/10.1080/10 962247.2017 .1316326

Landwirtschaftskammer Österreich. 2020. Holzmarktbericht 2020 (Wood market report 2020). cited in https://www.waldverband.at/ holzmarktbericht-der-lkoe-september-2020-2/ consulted on the 09.09.2021

Lechtenböhmer, S., Nilsson, L. J., Åhman, M., \& Schneider, C. 2016. Decarbonising the energy intensive basic materials industry through electrification-Implications for future EU electricity demand. Energy, 115, 1623-1631. doi: https://doi.org/10.1016/j.energy.2016.07.110

LFL. (2019). Biogasausbeute verschiedener Substrate (Biogas content from various substrates). cited in https://www.Ifl.bayern.de/iba/ energie/049711/?sel_list=20\%2Cb\&anker0=substratanker\#substratanker consulted on the 04.09.2019

Lindorfer, J., \& Schwarz, M. M. 2013. Site-specific economic and ecological analysis of enhanced production, upgrade and feed-in of biomethane from organic wastes. Water Sci Technol, 67(3), 682 688. doi: https://doi.org/10.2166/wst.2012.617

Luňáčková, P., Průša, J., \& Janda, K. 2017. The merit order effect of Czech photovoltaic plants. Energy Policy, 106, 138-147. doi: https://doi.org/10.1016/j.enpol.2017.02.053

Melikoglu, M., \& Menekse, Z. K. 2020. Forecasting Turkey's cattle and sheep manure based biomethane potentials till 2026. Biomass \& Bioenergy, 132, 105440. doi: https://doi.org/10.1016/j.biombioe.2019.105440

Müller, S. 2013. Hydrogen from biomass for industry-Industrial application of hydrogen production based on dual fluid gasification. (Dr. techn.). Technical University of Vienna, Vienna. cited in https://repositum.tuwien.at/handle/20.500.12708/14449 consulted on the 10.09.2021

Nelissen, D., Faber, J., van der Veen, R., van Grinsven, A., Shanthi, H. \& van den Toorn, E. 2020. Availability and costs of liquefied bioand synthetic methane: The maritime shipping perspective. cited in https://cedelft.eu/wp-content/uploads/sites/2/2021/03/CE Delft_190236_Availability_and_costs_of_liquefied_bio-_and_synthetic_methane_Def.pdf consulted on the 09.09.2021
O'Shea, R., Wall, D. M., Kilgallon, I., Browne, J. D., \& Murphy, J. D. 2017. Assessing the total theoretical, and financially viable, resource of biomethane for injection to a natural gas network in a region. Applied Energy, 188, 237-256. doi: https://doi.org/10.1016/j.apenergy.2016.11.121

O'Shea, R., Wall, D. M., McDonagh, S., \& Murphy, J. D. 2017. The potential of power to gas to provide green gas utilising existing $\mathrm{CO} 2$ sources from industries, distilleries and wastewater treatment facilities. Renewable Energy, 114, 1090-1100. doi: https://doi. org/10.1016/j.renene.2017.07.097

ÖVGW. 2011. ÖVGW Richtlinie G B220 Regenerative Gase - Biogas (ÖVGW Guideline G B220 renewable gases - biogas). cited in https://portal.ovgw.at/pls/f?p=101:203:.:.:RP,203:P203_ID,P203_ FROM_PAGE_ID:1075524,202 consulted on the 09.09.2021

Parra, D., Zhang, X., Bauer, C., \& Patel, M. K. 2017. An integrated techno-economic and life cycle environmental assessment of powerto-gas systems. Applied Energy, 193, 440-454. doi: https://doi. org/10.1016/j.apenergy.2017.02.063

Reisinger, H. 2012. Rückstände aus der Nahrungs-und Genussmittelproduktion (Residues from food and luxury food production) cited in https://www.umweltbundesamt.at/fileadmin/site/publikationen/REP0403.pdf consulted on the 09.09.2021

Republik Österreich. 2020. Aus Verantwortung für Österreich. Regierungsprogramm 2020-2024 (Out of responsibility for Austria. Govermental program 2020-2024). cited in https://www. dieneuevolkspartei.at/Download/Regierungsprogramm_2020.pdf consulted on the 09.09.2021

Rodin, V., Lindorfer, J., Bohm, H., \& Vieira, L. 2020. Assessing the potential of carbon dioxide valorisation in Europe with focus on biogenic CO2. Journal of CO2 Utilization, 41, 101219. doi: https://doi. org/10.1016/j.jcou.2020.101219

Rosenfeld, D. C. 2020. Generation and application of renewable gases as sustainable energy carrier for industry and mobility. ( $\mathrm{Dr}$ Dissertation). University of Natural Resources and Life Sciences, Vienna, Austria. cited in https://forschung.boku.ac.at/fis/suchen. hochschulschriften_info?sprache_in=de\&menue_id_in=107\&id_in$=$ \&hochschulschrift_id_in=19542 consulted on the 10.09.2021

Rosenfeld, D. C., Lindorfer, J., \& Ellersdorfer, M. 2020. Valorization of organic waste fractions: a theoretical study on biomethane production potential and the recovery of $\mathrm{N}$ and $\mathrm{P}$ in Austria. Energy Sustainability and Society, 10(1), 1-11. doi: https://doi.org/10.1186/ s13705-020-00272-3

Schiffer, Z. J., \& Manthiram, K. 2017. Electrification and decarbonization of the chemical industry. Joule, 1(1), 10-14. doi: https://doi. org/10.1016/j.joule.2017.07.008

Sensfuß, F., Ragwitz, M., \& Genoese, M. 2008. The merit-order effect: A detailed analysis of the price effect of renewable electricity generation on spot market prices in Germany. Energy Policy, 36(8), 30863094. doi: https://doi.org/10.1016/j.enpol.2008.03.035

Singlitico, A., Goggins, J., \& Monaghan, R. F. D. 2018. Evaluation of the potential and geospatial distribution of waste and residues for bioSNG production: A case study for the Republic of Ireland. Renewable \& Sustainable Energy Reviews, 98, 288-301. doi: https://doi. org/10.1016/j.rser.2018.09.032

Skovsgaard, L., \& Jacobsen, H. K. 2017. Economies of scale in biogas production and the significance of flexible regulation. Energy Policy, 101, 77-89. doi: https://doi.org/10.1016/j.enpol.2016.11.021

Smolinka, T., Wiebke, N., Sterchele, P., Lehner, F., \& Jansen, M. 2018. Sudie_IndWEDe-Industrialisierung der Wasserelektrolyse in Deutschland: Chancen und Herausforderungen für nachhaltigen Wasserstoff für Verkehr, Strom und Wärme (Industrialization of water electrolysis in germany: Chances and challenges for sustainable hydrogen in mobility, electricity and heat). cited in https:// www.dwv-info.de/wp-content/uploads/2019/06/NOW-Elektrolysestudie-2018.pdf consulted on the 09.09.2021

Steinmüller, H., Reiter, G., Tichler, R., Friedl, C., Furtlehner, M., Lindorfer, J., Schwarz, M., Koppe, M., Biegger, P., \& Felder, A. 2014. Power to Gas-eine Systemanalyse: Markt-und Technologiescouting und-analyse (Power to Gas - a system analysis: market and technology scouting and analysis). cited in https://www.ea.tuwien.ac.at/fileadmin/t/ea/projekte/PtG/Endbericht_-_Power_to_Gas_-_eine_Systemanalyse_-_2014.pdf consulted on the 10.09.2021

Steubing, B., Zah, R., Waeger, P., \& Ludwig, C. 2010. Bioenergy in Switzerland: Assessing the domestic sustainable biomass potential. Renewable \& Sustainable Energy Reviews, 14(8), 2256-2265. doi: https://doi.org/10.1016/j.rser.2010.03.036 
Strimitzer, L., \& Höher, M. 2020. Holzströme in Österreich (Wood streams in Austria). cited in https://www.klimaaktiv.at/erneuerbare/energieholz/holzstr_oesterr.html consulted on the 09.09.2021

Swanson, R. M., Platon, A., Satrio, J. A., \& Brown, R. C. 2010. Techno-economic analysis of biomass-to-liquids production based on gasification. Fuel, 89, S11-S19. doi: https://doi.org/10.1016/j. fuel.2010.07.027

Thrän, D., Pfeiffer, D., Brosowski, A., Fischer, E., Herrmann, A., Majer, S., Oehmichen, K., Schmersahl, R., Schröder, T., \& Stecher, K. 2013. Methodenhandbuch Stoffstromorientierte Bilanzierung der Klimagaseffekte (Methods manual material flow-oriented balancing of greenhouse gas effects). cited in https://www.energetische-biomassenutzung.de/fileadmin/media/6_Publikationen/04_Methodenhandbuch_2013_final.pdf consulted on the 09.09.2021

Thunman, H., Seemann, M., Vilches, T. B., Maric, J., Pallares, D., Strom, H., Berndes, G., Knutsson, P., Larsson, A., Breitholtz, C., \& Santos, O. 2018. Advanced biofuel production via gasification - lessons learned from 200 man-years of research activity with Chalmers' research gasifier and the GoBiGas demonstration plant. Energy Science \& Engineering, 6(1), 6-34. doi: https://doi.org/10.1002/ ese3.188

Tichler, R., \& Zauner, A. 2018. Perspectives of the Gas Sector - GREENING THE GAS. Renewable Energy Law and Policy Review, 8(4), 4248. doi: https://doi.org/10.2307/26638285
TNO. (2021). Database for the physico-chemical composition of (treated) lignocellulosic biomass, micro- and macroalgae, various feedstocks for biogas production and biochar. cited in https://phyllis. $\mathrm{nl} /$ consulted on the 05.03.2021

Universität Rostock, I. f. E. u. U. g., ; Bundesforschungsanstalt für Landwirtschaft, . 2007. Biogaserzeugung durch Trockenvergärung von organischen Rückständen, Nebenprodukten und Abfällen aus de Landwirtschaft (Biogas production via dry anerobic digestion of organic residues, by-products and wastes from agriculture). cited in https://www.infothek-biomasse.ch/images/2007_FNR_Trockenvergaerung.pdf consulted on the 09.09.2021

van Melle, T., Peters, D., Cherkasky, J., Wessels, R., Mir, G. R., \& Hofsteenge, W. 2018. Gas for Climate: How gas can help to achieve the Paris Agreement target in an affordable way. cited in https:// gasforclimate2050.eu/ consulted on the 09.09.2021

Vienna University of Technology. 2012. Biogas to biomethane. Technology review. cited in https://www.membran.at/downloads/2012_BioRegions_BiogasUpgradingTechnologyReview_ENGLISH.pdf consulted on the 09.09.2021

Wang, S. L., Jena, U., \& Das, K. C. 2018. Biomethane production potential of slaughterhouse waste in the United States. Energy Conversion and Management, 173, 143-157. doi: https://doi.org/10.1016/j.enconman.2018.07.059

Xie, L., MacDonald, S. L., Auffhammer, M., Jaiswal, D., \& Berck, P. 2019. Environment or food: Modeling future land use patterns of miscanthus for bioenergy using fine scale data. Ecological economics, 161, 225-236. doi: https://doi.org/10.1016/j.ecolecon.2019.03.013

\section{APPENDIX}

TABLE A6: Substrate potential for the different Austrian states (Bundesanstalt für Agrarwirtschaft, 2016; Bundesministerium Nachhaltigkeit und Tourismus, 2019; FNR, 2013; Reisinger, 2012; Universität Rostock, 2007).

\begin{tabular}{|c|c|c|c|c|c|c|c|c|c|c|}
\hline $\begin{array}{l}\text { substrate } \\
\text { potential [t/a] }\end{array}$ & 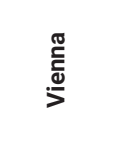 & 㐫 & 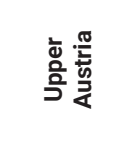 & 焉 & $\begin{array}{l}\text { 잏 } \\
\frac{\hat{D}}{N} \\
\text { 心 }\end{array}$ & 힌 & 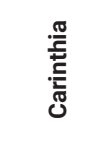 & 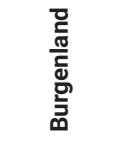 & $\begin{array}{l}\text { 인 } \\
\text { 인 } \\
\text { 힌 } \\
\text { गे }\end{array}$ & $\underset{\frac{\pi}{2}}{\stackrel{0}{\frac{0}{3}}}$ \\
\hline sewage sludge & 71.000 & 44.500 & 37.000 & 21.200 & 13.200 & 17.200 & 12.500 & 8.800 & 10.800 & 236.200 \\
\hline $\begin{array}{l}\text { bio waste from } \\
\text { households }\end{array}$ & 92.408 & 149.115 & 77.462 & 68.773 & 37.005 & 53.301 & 15.166 & 15.819 & 16.702 & 525.751 \\
\hline $\begin{array}{l}\text { bush-, grass- } \\
\text { and tree-cuts }\end{array}$ & 11.550 & 134.904 & 162.670 & 44.161 & 22.398 & 51.193 & 13.528 & 22.679 & 13.469 & 476.552 \\
\hline straw & 250 & 1.132 .645 & 491.064 & 256.093 & 61.144 & 1.178 & 201.018 & 287.549 & 250 & 2.431 .191 \\
\hline manure & 728 & 1.854 .860 & 2.548 .075 & 1.581 .797 & 344.251 & 382.069 & 546.984 & 100.962 & 142.270 & 7.501 .996 \\
\hline $\begin{array}{l}\text { waste from food } \\
\text { production * }\end{array}$ & 264.623 & 233.949 & 206.692 & 173.356 & 77.431 & 105.251 & 78.228 & 40.922 & 54.988 & 1.235 .441 \\
\hline $\begin{array}{l}\text { other biogenic } \\
\text { wastes * }\end{array}$ & 131.643 & 116.384 & 102.824 & 86.240 & 38.520 & 52.360 & 38.917 & 20.358 & 27.355 & 614.600 \\
\hline total & 572.203 & 3.666 .357 & 3.625 .787 & 2.231 .619 & 593.949 & 662.551 & 906.341 & 497.089 & 265.835 & 13.021.731 \\
\hline
\end{tabular}

* cumulative value for Austria segmented according to the population share of the specific state 